The author on the basis of the analyses of the state statistical data concluded, that indexes of the illegal mining of mineral resources in Ukraine during 2013-2018 are characterizing by instability. The last tendency of it is the sharp decrease of crime rate and some rising of incarceration rate of crimes under Article 240 of the Criminal Code of Ukraine. The unit weight of these crimes in the structure of crimes against the environment consist $10-24 \%$ and $20-30 \%$ of the convicted persons for committing a crime against the environment.

Crimes under Article 240 of the Criminal Code of Ukraine have the next criminal law characteristics: these are intended mercenary continuous crimes that are usually committed by a few persons (joint crimes). The most popular target of crime is amber.

The criminological structure of illegal mining of mineral resources in Ukraine shows that: its "geography" is inextricably linked with the places of mineral resources deposits; such crimes are committed outside large cities; the tools, used by criminals, in the overwhelming majority, are primitive, that testify about absence of the necessity of a high engineering and technical level of training for preparing these crimes committing; the overwhelming majority of crimes are committed at night; their commission has a seasonal character, etc.

Key words: illegal mining of mineral resources, station of crime, mineral resources, amber.

DOI https://doi.org/10.33766/2524-0323.87.268-280 УДК 343.98

А. М. Лисенко,

кандидат юридичних наук, доцент, доцент кафедри оперативно-розшукової діяльності

Харківського національного університету внутрішніх справ

(м. Харків, Україна)

e-mail: lan11.07.1979@gmail.com

iD https:// orcid.org/0000-0003-0780-2148

I. В. Лисенко,

кандидат юридичних наук, доцент, доцент кафедри права Національного технічного університету «Харківський політехнічний інститут» (м. Харків, Україна) e-mail: irina8119@ukr.net

iD https://orcid.org/0000-0003-3392-6056

Л. В. Перевалова, кандидат філософських наук, доцент, завідувач кафедри права Національного технічного університету «Харківський політехнічний інститут»

(м. Харків, Україна)

e-mail: perevalovaluda@ukr.net

iD https://orcid.org/0000-0001-5182-2838

\title{
ІНФОРМАЦЙНО-АНАЛІТИЧНЕ ЗАБЕЗПЕЧЕННЯ ОПЕРАТИВНО- РОЗШУКОВОЇ ДІЯЛЬНОСТІ ЩОДО ПРОТИДІЇ ТЕРОРИЗМУ
}

У даній науковій статті розглядаються зміст та сутність інформаційноаналітичного забезпечення оперативно-розшукової діяльності щодо протидії 
тероризму з метою виявлення існуючих недоліків у цій сфері. Під час дослідження були використані результати аналізу опрацьованої спеціальної фахової літератури, законодавчих актів, практичного досвіду протидії злочинам, пов'язаних із тероризмом та особистого досвіду роботи в правоохоронних органах. Автори надали науково-обгрунтовані пропозиції щодо удосконалення інформаційно-аналітичного забезпечення зазначеної діяльності.

Ключові слова: інформаційно-аналітичне забезпечення, оперативнорозшукова інформація, джерела оперативно-розшукової інформації, оперативнорозшукова діяльність, тероризм.

Постановка проблеми. Оперативно-розшукова діяльність щодо протидії тероризму в сучасних умовах пов'язана 3 опрацюванням значної кількості джерел, а також роботою 3 великою кількістю інформації, тому істотним фактором, що впливає на ефективність боротьби зі злочинністю, є правильно організоване інформаційно-аналітичне забезпечення оперативно-розшукової діяльності. Однак, як свідчить практичний досвід, інформаційно-аналітичне забезпечення за цією лінією роботи здійснюється на неналежному рівні у зв'язку з наявністю певних недоліків організаційного характеру. До таких недоліків, насамперед, належить недосконалість системи збору інформації, недоліки ії накопичення та використання.

Аналіз останніх досліджень і публікацій. У науці поняття «оперативнорозшукова діяльність та «інформаційно-аналітичне забезпечення» розглядалося багатьма вченими як на рівні окремих монографічних досліджень, так і в комплексі $з$ дослідженням інших організаційних аспектів оперативнорозшукової діяльності. Серед таких досліджень слід виділити праці таких учених: К. В. Антонова [1], О. М. Бандурки [2], Г. М. Воскресенського [3], Е. О. Дідоренка [4], І. П. Козаченка [5], А. М. Лисенка [6], В. Л. Регульського [5] та ін.

У наведених дослідженнях та в деяких інших працях учених були визначені фундаментальні теоретичні основи інформаційно-аналітичного забезпечення оперативно-розшукової діяльності, на які ми будемо, безумовно, спиратися, під час проведення нашого дослідження. Однак, враховуючи сучасні зміни у сфері інформаційних технологій, криміногенної обстановки в Україні, чинного законодавства, виникає нагальна необхідність окремого дослідження інформаційно-аналітичного забезпечення оперативно-розшукової діяльності щодо протидії тероризму.

Формування цілей. На підставі комплексного аналізу спеціальних фахових досліджень із питань інформаційно-аналітичного забезпечення оперативно-розшукової діяльності було встановлено, що саме питання інформаційно-аналітичного забезпечення протидії тероризму залишаються мало дослідженими в Україні. Враховуючи це, автори поставили за мету визначити притаманні йому недоліки та запропонувати шляхи їх усунення.

Виклад основного матеріалу. Ефективність протидії тероризму залежить від рівня обізнаності правоохоронних органів про кримінальні процеси, що відбуваються на території оперативного обслуговування, тобто від рівня інформаційно-аналітичного забезпечення їх діяльності. Без наявності достатнього обсягу інформації вирішення завдань оперативно-розшукової 
діяльності буде носити несистемний, випадковий характер. 3 метою недопущення такого становища, кожен окремий працівник оперативного підрозділу з моменту початку своєї служби вживає заходів щодо пошуку та використання різноманітних джерел отримання інформації, яка характеризує оперативну обстановку. Уся одержана оперативними працівниками інформація повинна аналізуватися, фіксуватися та накопичуватися з метою зручності іiі використання в спеціальних справах та автоматизованих інформаційних системах.

Разом із тим, у практичній діяльності спостерігаються значні недоліки в організації інформаційно-аналітичного забезпечення оперативнорозшукової діяльності щодо протидії тероризму, насамперед, на тактичному рівні. До головних таких недоліків можна віднести неспроможність окремих оперативних працівників одержувати актуальну оперативно-розшукову інформацію про підготовку даних злочинів та причетних до цього осіб, визначати джерела вірогідного одержання інформації, невміння здійснювати правильну оцінку вже одержаної інформації та використовувати ії найбільш ефективним шляхом. Причинами існування зазначених недоліків є недостатній досвід роботи за даною лінією як оперативних працівників, так i їхніх керівників. Це створює значні складнощі при підготовці нових оперативних працівників, що досить часто зумовлене відсутністю компетентних та досвідчених наставників. Основним призначенням наставників $є$ надання допомоги в адаптуванні нових оперативних працівників у підрозділі та використанні отриманих ними під час навчання знань безпосередньо в практичній діяльності.

У теорії оперативно-розшукової діяльності, незважаючи на деякі відмінності в поглядах науковців щодо визначення терміну «інформаційно-аналітичне забезпечення», існує і його усталене поняття. Проаналізуємо погляди провідних учених з цього питання. Отже, на їх думку, це: діяльність, яка організовується в рамках управління і спрямована на проектування, функціонування та вдосконалення інформаційних систем, які забезпечують ефективне виконання завдань управління [3, с. 21.]; циклічний процес пошуку, збору, обробки, переосмислення, зберігання, видачі інформації та ії використання для прийняття оперативно - тактичних й інших правоохоронних рішень [5, с. 124]; це комплекс заходів, здійснюваних підрозділами органів внутрішніх справ, спрямованих на пошук, збір, аналіз, збереження та використання інформації з метою прийняття відповідних рішень щодо боротьби зі злочинністю [7, с. 79].

Таким чином, інформаційно-аналітичне забезпечення оперативнорозшукової діяльності - це низка дій з інформацією, спрямованих на забезпечення зручності ії використання та підвищення за допомогою цього обізнаності оперативних підрозділів про кримінальні процеси, які відбуваються в суспільстві.

Основним елементом інформаційно-аналітичного забезпечення виступає інформація. Так відсутність інформації про злочин не дозволяє ефективно та цілеспрямовано виявляти та документувати його. Оперативно- 
розшукова інформація є різновидом загальної інформації та відрізняється від неї своїм призначенням, яке відбивається в ії назві.

Ми підтримуємо думку Г. О. Душейка, який цілком правильно вважає, що в системі інформаційного забезпечення правоохоронних органів за ознаками новизни й періодичності надходження необхідно розрізняти два види оперативно-розшукової інформації: 1) первинні дані, тобто раніше невідома інформація, що становить оперативний інтерес; 2) інформація, що перевірена, накопичена, врахована внаслідок здійснення оперативнорозшукових заходів і пристосована для використання в боротьбі зі злочинністю [11, с. 87]. Наведені види оперативно-розшукової інформації розрізняються між собою за новизною змісту інформації та послідовністю ï отримання оперативними працівниками. Взаємозв'язок первинної та наступної оперативно-розшукової інформації полягає в тому, що перша 3 них завжди підлягає перевірці та уточненню оперативними працівниками за допомогою проведення певних заходів, у тому числі, оперативно-розшукових, у результаті чого ними одержується саме другий вид інформації.

Під час проведення дослідження нами було встановлено, що в процесі організації та здійснення оперативно-розшукової діяльності щодо протидії тероризму, оперативним працівникам не складало великих труднощів отримати первинну оперативно-розшукову інформацію про факти вчинення злочинів. На підставі одержання первинної оперативнорозшукової інформації про злочини, у $56 \%$ оперативних працівників підрозділів карного розшуку НПУ та СБУ в подальшому виникали складнощі з отриманням більш детальної інформації про механізм та обстановку їх вчинення, а також осіб, причетних до їх вчинення (опитування проводилося в 2019 році серед працівників, які проходили підвищення кваліфікації в Харківському національному університеті внутрішніх справ (289 осіб), та Національній академії СБУ (108 осіб)).

У процесі організації та налагодження інформаційно-аналітичного забезпечення оперативно-розшукової діяльності за розглядуваною лінією роботи найважливішу роль відіграє своєчасне та правильне визначення джерел надходження інформації про терористичну діяльність. Такий підхід обумовлений тим, що здійснення будь-яких дій (перевірка, обробка, аналіз, накопичення тощо) з отриманою оперативно-розшуковою інформацією має другорядне значення по відношенню до ії безпосереднього отримання. Саме отримання інформації є початковим етапом інформаційно-аналітичної роботи; тільки з нього можуть починатися будь-які дії з інформацією; в інший же спосіб провадити їх неможливо. Зазначимо, що отримання оперативно-розшукової інформації є найскладнішою елементом роботи в системі інформаційно-аналітичного забезпечення та в деякій мірі залежить від фактору везіння.

3 метою отримання оперативно-розшукової та іншої інформації про терористичну діяльність, оперативний працівник повинен визначити вірогідні джерела ії надходження. 3 приводу використання в оперативнорозшуковій діяльності різноманітних джерел отримання інформації О. М. Бандурка цілком влучно зазначає, що «коли оперативний працівник 
виявляє намір скористатись якимось джерелом інформації, він повинен уяснити його наявні й потенційні можливості, допустимі межі використання, ступінь надійності такого джерела інформації. Оперативний працівник сам вибирає конкретні форми пошуку інформації залежно від цілей і завдань, поставлених перед ним, а також залежно від ситуації, яка складується» [2, с. 290].

Під час провадження оперативно-розшукової діяльності щодо протидії тероризму нерідко в оперативних працівників карного розшуку та СБУ виникає нагальна необхідність у підвищенні рівня своєї обізнаності про особистості терористів, їх зв'язки, місце, спосіб підготовки або вчинення злочину та інші обставини. Наше дослідження показало, що 3 цією метою ними використовувалися такі джерела інформації, як: автоматизовані інформаційно-пошукові системи правоохоронних органів (22 \%); обліки та інформаційні системи інших державних установ (26\%); обліки осіб, причетних до вчинення злочинів (24 \%); матеріали кримінальних проваджень та архівних кримінальних справ (5 \%); неавтоматизовані інформаційні обліки (справи) (14 \%); матеріали оперативно-розшукових справ (7 \%) та інші (2 \%).

Слід зазначити, що при організації інформаційно-аналітичного забезпечення оперативно-розшукової діяльності щодо протидії тероризму немає сенсу враховувати такий принцип, як достатність джерел інформації, адже обсяг отриманої оперативно-розшукової інформації не може бути завеликим. Пошук джерел інформації та їх використання щодо протидії тероризму повинні здійснюватися цілеспрямовано, на систематичній основі. Такий підхід має забезпечити постійне надходження оперативно-розшукової інформації до оперативних підрозділів з метою здійснення ефективного спостереження за криміногенними процесами, що відбуваються за даною лінією роботи, та своєчасного виявлення злочинів, що готуються, встановлення осіб, які готують або вчинили злочин, розшуку осіб, котрі переховуються від органів дізнання, слідства, суду.

Незалежно від того, з якого джерела одержана оперативно-розшукова інформація про злочин, оперативний працівник повинен здійснювати іï аналіз, при цьому необхідно співвідносити інформацію, одержану 3 різних джерел, між собою з метою встановлення розбіжностей у їх змісті та отримання нової, більш достовірної інформації. П. Я. Мінка зазначає, що першочергова оцінка отриманих відомостей передбачає їх аналіз з позиції об'єктивності та корисності. Таку оцінку здійснюють оперативні працівники, які збирають відповідну інформацію, адже вони мають у своєму розпорядженні всі дані про саму оцінювану інформацію, а також про іï джерело [12, с. 155-182]. Таким чином, відбувається аналітична робота, а оперативний працівник здійснює відповідно аналітичний пошук інформації. Схожу думку має і В. Б. Рушайло, який наголошує на тому, що діяльність оперативних підрозділів «... має поєднувати оперативний та аналітичний пошуки інформації, адже первинні дані, що були зібрані під час оперативного пошуку, систематизуються, доповнюються попередніми даними, зіставляються 3 ними та узагальнюються для подальшого використання» [13, с. 469]. 
Під час організації інформаційно-аналітичного забезпечення оперативнорозшукової діяльності, як правило, застосовується система подвійного аналізу одержаної інформації, що складається з їі аналізу на тактичному рівні, який здійснюється безпосередньо оперативним працівником та керівником оперативного підрозділу, та аналізу на стратегічному рівні, який здійснюється працівниками підрозділів інформаційно-аналітичної підтримки. Таким чином, усі інформаційні потоки в кінщевому результаті стікаються до підрозділів інформаційно-аналітичної підтримки, що створює належні умови для використання різноманітної інформації будь-яким підрозділом правоохоронного органу. Така система організації опрацювання інформації повинна забезпечувати міцне підгрунтя для інформаційно-аналітичного забезпечення діяльності оперативних підрозділів.

Поряд зі збором та аналізом оперативно-розшукової інформації не менше значення має іï накопичення та зберігання з метою недопущення втрачання важливих для оперативно-розшукової діяльності відомостей та подальшого їх зручного використання. Для забезпечення накопичення та зберігання оперативно-розшукової інформації вона систематизується та вноситься до автоматизованих інформаційно-пошукових систем, а також відповідних неавтоматизованих спеціальних обліків (справ), які ведуться безпосередньо в оперативних підрозділах. Слід звернути увагу на те, що право оперативних підрозділів на створення і застосування автоматизованих інформаційних систем має законодавче закріплення. Указане право передбачене п. 18 ч. 1 статті 8 Закону України «Про оперативно-розшукову діяльність» [14, ст. 8], що є, на нашу думку, позитивним рішенням законодавця в регламентації організації оперативно-розшукової діяльності.

Необхідно зазначити, що використання працівниками оперативних підрозділів ресурсів різноманітних інформаційно-пошукових систем покликане сприяти підвищенню рівня інформаційно-аналітичного забезпечення їх діяльності під час виявлення та попередження злочинів, виконання інших завдань оперативно-розшукової діяльності та доручень слідчого щодо проведення негласних слідчих (розшукових) дій у межах досудового розслідування злочинів.

Разом із тим анкетування оперативних працівників підрозділів карного розшуку та СБУ свідчить про те, що автоматизовані інформаційно-пошукові системи використовуються в практичній діяльності незадовільно. Так 42 \% опитаних відповіли, що отримували інформацію із вказаних систем лише 3 метою формального виконання вимог керівництва, а 38 \% - взагалі не отримували такої інформації під час боротьби зі злочинністю.

Аналіз наукових досліджень та результатів анкетування оперативних працівників підрозділів карного розшуку та СБУ дозволили нам визначити основні причини низького рівня застосування даних автоматизованих інформаційно-пошукових систем, а саме: 1) складність та незручність отримання інформації із вказаних систем; 2) існування думки про низьке значення використання інформації, яка міститься в автоматизованих інформаційно-пошукових системах, для боротьби зі злочинністю; 3) відсутність знань про можливості автоматизованих інформаційно- 
пошукових систем; 4) відсутність навичок отримання інформації 3 розглядуваних систем.

Ми вважаємо, що в основі наведених причин лежать такі негативні явища в діяльності оперативних підрозділів, як: низький рівень професійної підготовки окремих працівників цих підрозділів, їх незначний досвід практичної діяльності та самовпевненість щодо спроможності самостійно вирішувати завдання оперативно-розшукової діяльності, поверхове ставлення до виконання своїх обов'язків. Для вирішення цих проблем необхідне вжиття керівництвом правоохоронних органів заходів щодо організації в оперативних підрозділах практичних занять зі службової підготовки за участю як більш досвідчених оперативних працівників, так і працівників підрозділів інформаційно-аналітичної підтримки. Під час таких занять необхідно роз'яснити оперативним працівникам про таке: можливості використання автоматизованих інформаційно-пошукових систем; зміст інформації, яка в них міститься; способи іï отримання, а також важливість відповідального ставлення кожного окремого працівника щодо своєчасного та якісного внесення до даних систем отриманої оперативно-розшукової інформації.

Слід зауважити, що певна частина оперативних працівників підрозділів карного розшуку та СБУ (27 \%) під час анкетування зазначила, що не вважає важливим внесення інформації до автоматизованих інформаційнопошукових систем. На нашу думку, такий підхід до організації інформаційно-аналітичного забезпечення оперативно-розшукової діяльності $є$ неприпустимим. Це обумовлено тим, що навіть за умов ефективного використання отриманої оперативно-розшукової інформації, без їі систематизації та накопичення, вона буде використовуватися лише на тактичному рівні, тобто для досягнення конкретної цілі (попередження, виявлення, припинення злочину тощо). При цьому використання оперативно-розшукової інформації в стратегічних цілях, тобто для інформування інших оперативних підрозділів та їх працівників, визначення тенденцій розвитку злочинності тощо, стає малоймовірним.

Ми повністю поділяємо думку О. М. Бандурки, який вважає, що «одне 3 основних завдань, яке потребує подальшого вирішення, це підняття ступеня готовності оперативних підрозділів до роботи з інформаційними системами, до активного використання ними новітніх інформаційних технологій у свойй професійній діяльності». Далі він зазначає, що «на цей час існує певний психологічний бар'єр щодо їх використання, для подолання якого необхідна кропітка цілеспрямована робота серед працівників оперативних підрозділів, подолання сформованих стереотипів, фактично переосмислення традиційних підходів та методів, формування нового - системного мислення, оволодіння умінням бачити в нових інформаційних технологіях не тільки систему знань, але й сукупність практичних прийомів, методів і засобів, що розширюють межі можливостей користувачів таких систем» [2, с. 286].

Крім автоматизованих інформаційно-пошукових систем оперативного призначення, оперативно-розшукова інформація повинна накопичуватися в спеціальних неавтоматизованих обліках (справах), які заводяться за 
ініціативою оперативних підрозділів з метою відстеження, аналізу й оцінки оперативної обстановки на території оперативного обслуговування чи за лінією роботи. Оперативні підрозділи ведуть, насамперед, облік осіб, що причетні до підготовки та вчинення злочинів, пов'язаних із терористичною діяльністю; переховуються від органів досудового розслідування, слідчого судді, суду або ухиляються від відбування кримінального покарання; раніше судимих за вчинення даних злочинів; відносно яких кримінальне переслідування за вчинення злочину було припинено за нереабілітуючими обставинами; становлять оперативний інтерес у зв'язку 3 отриманням достовірної інформації про підготовку або вчинення ними злочину тощо. Зазначені обліки можуть містити до себе також картотеки, фотоальбоми, відеотеки, дактилоскопічні карти. Слід зазначити, що, на відміну від незадовільного використання працівниками оперативних підрозділів ресурсів автоматизованих інформаційно-пошукових систем, використання відомостей, що містяться в спеціальних неавтоматизованих обліках (справах), особливо тих, що ведуться безпосередньо оперативними працівниками, носять більш системний характер. Так 81 \% опитаних працівників оперативних підрозділів відповіли, що ознайомлювалися під час боротьби зі злочинністю 3 інформацією, яка була накопичена в зазначених обліках (справах).

На нашу думку, головною причиною більш високого рівня використання оперативними працівниками інформації, яка міститься в спеціальних неавтоматизованих обліках (справах), є простота доступу до них у порівнянні з автоматизованими інформаційно-пошуковими системами оперативного призначення, оскільки перші ведуться безпосередньо в оперативному підрозділі або взагалі знаходяться в провадженні оперативного працівника. При цьому оперативні працівники не враховують того факту, що в автоматизованих інформаційно-пошукових системах оперативного призначення міститься, як правило, більш повна інформація про осіб та події, які становлять оперативний інтерес, у зв'язку з тим що ії надходження забезпечується всіма оперативними підрозділами.

Висновки. Таким чином, аналізуючи дані, отримані під час нашого дослідження, можна зробити висновок, що причинами незадовільного стану здійснення інформаційно-аналітичного забезпечення оперативнорозшукової діяльності щодо протидії тероризму є не тільки протидія з боку злочинців (насамперед, приховування своєї злочинної діяльності), але й причини організаційного характеру (недоліки в зборі, накопичені та використані оперативно-розшукової інформації). Враховуючи складний стан криміногенної обстановки в сучасній Україні, пов' язаний зі зростанням рівня терористичної загрози, вважаємо неприпустимим таке становище.

Ми вважаємо, що, 3 метою розв'язання цих проблем, необхідне використання важелів адміністративного управління з боку керівництва оперативних підрозділів та вжиття заходів щодо:

1. Збереження кадрового складу оперативних підрозділів, особливо осіб, які мають досвід практичної діяльності понад 5 років, та створення 3 цією метою відповідних умов праці. При цьому, враховуючи складну ситуацію в економічній галузі Украӥни, ми не наголошуємо на такому заході, як значне 
підвищення рівня матеріального забезпечення, розуміючи його неможливість, однак вважаємо необхідним неухильне дотримання керівництвом оперативних підрозділів норм трудового законодавства, які не повинні порушуватися без нагальної необхідності. Особливо це стосується тривалості робочого дня та кількості вихідних днів. У практичній діяльності спостерігається негативна тенденція повсюдного попрання трудових прав оперативних працівників з боку керівнищтва. Це призводить у кінщевому результаті до зниження працездатності та відсутності зацікавленості в такій роботі з боку оперативних працівників, які або звільняються за власним бажанням, або переводяться до інших підрозділів із меншим робочим навантаженням. Втрата досвідчених працівників, яка при цьому відбувається, негативно відбивається і на стажуванні нових оперативних працівників, адже їм фактично немає від кого отримувати практичні поради. Безперечним є той факт, що навіть досконале знання оперативним працівником теорії оперативно-розшукової діяльності не забезпечує ефективного розкриття злочинів без наявності практичних навичок. Дана обставина негативно відбивається й на якості інформаційно-аналітичного забезпечення оперативнорозшукової діяльності, яке є одним зі складових елементів протидії злочинності.

2. Підвищення рівня початкової професійної підготовки працівників оперативних підрозділів та навчання курсантів у вищих навчальних закладах зі специфічними умовами навчання. При цьому керівництву даних закладів необхідно приділити належну увагу залученню до праці на кафедрах оперативно-розшукової діяльності, криміналістики, кримінального процесу та кримінального права досвідчених практичних працівників оперативних підрозділів, навіть за відсутності в них учених звань та наукових ступенів. Дана категорія викладацького складу має особливе значення для проведення практичних та семінарських занять із курсантами та слухачами, саме під час яких набуваються навички та вміння провадження оперативно-розшукової діяльності, у тому числі, й щодо їі інформаційно-аналітичного забезпечення.

3. Зміни системи критеріїв оцінки діяльності оперативних підрозділів шाяхом заміни кількісних показників розкритих злочинів на оцінку за станом поширеності злочинів на території оперативного обслуговування. Указаний захід створить належні умови для протидії тероризму та призведе до зниження навантаження на оперативних працівників, що дозволить їм зосередитися на якісній організації та провадженні інформаційно-аналітичного забезпечення своєї діяльності.

\section{Використані джерела:}

1. Антонов К. В. Державно-правове забезпечення економічної безпеки України від злочинних посягань :теоретичні і організаційно-тактичні засади діяльності підрозділів ДСБЕЗ ОВС: автореф. дис. на здобуття наукового ступеня доктора юрид. наук : 21.07.04. Харків, 2005. 40 с.

2. Бандурка О. М. Оперативно-розшукова діяльність. Частина I : підручник. Харків. : Національний університет внутрішніх справ, 2002. 336 с.

3. Воскресенский Г. М. Теория и практика информационного обеспечения управления в органах внутренних дел: учебно-методические рекомендации. Москва: Академия МВД СССР, 1985. 38 с. 
4. Оперативно-розшукова діяльність органів внутрішніх справ. Загальна частина: підручник / Е. О. Дідоренко та ін.; за заг. ред. Л. В. Бородича. Луганськ: Луганський інститут внутрішніх справ, 1999. Т. 1.392 с.

5. Козаченко І. П., Регульський В. Л. Правові, морально-етичні та організаційні основи оперативно-розшукової діяльності : монографія. Львів: Львівский інститут внутрішніх справ при Національній академії внутрішніх справ України, 1999. 219 с.

6. Протидія одержанню неправомірної вигоди службовою особою підрозділами захисту економіки національної поліції України : монографія / А. М. Лисенко та ін. Харків: Видавництво «Форт», 2017. 178 с.

7. Лисенко А. М. Правові та організаційно-тактичні основи розкриття злочинів у сфері виготовлення та збуту алкогольних напоїв: дис. на здобуття наукового ступеня канд. юрид. наук : 21.07.04. Харків, 2008. 223 с.

8. Про інформацію: Закон України від 02 жовт. 1992 р. № 2657-XII. URL: https:/ /zakon.rada.gov.ua/laws/show/2657-12 (дата звернення: 21.02.2019).

9. Атмажитов В. М. Реализация оперативно-розыскной информации: лекция. Москва: Академия МВД СССР. 1984. 67 с.

10. Перепелищя М. М., Журавльов В. Ю. Деякі теоретичні аспекти інформаційного забезпечення оперативно-розшукової діяльності органів внутрішніх справ. Вісник Національного університету внутрішніх справ. 1999. Спец. вип. № 1. С. 37-46.

11. Душейко Г. О. Організаційно-тактичні основи реалізації оперативнорозшукової інформації на стадії порушення кримінальної справи: дис. на здобуття наукового ступеня канд. юрид. наук: 21.07.04. Харків, 2001. 268 с.

12. Мінка П. Я. Попередження оперативно-розшуковими заходами злочинних посягань на вантажі : дис. на здобуття наукового ступеня канд. юрид. наук: 21.07.04. Харків, 2003. 261 с.

13. Основы оперативно-розыскной деятельности: учебник для юридических вузов / под ред. В. Б. Рушайло. Санкт-Петербург: Лань, 2001. 720 с.

14. Про оперативно-розшукову діяльність: Закон України від 18 лют. 1992 р. № 2135-XII. URL: https://zakon.rada.gov.ua/laws/show/2135-12 (дата звернення: 21.02.2019).

\section{References:}

1. Antonov, K. V. (2005) Derzhavno-pravove zabezpechennia ekonomichnoi bezpeky Ukrainy vid zlochynnykh posiahan :teoretychni i orhanizatsiino-taktychni zasady diialnosti pidrozdiliv DSBEZ OVS. Extended abstract of candidate's thesis. Kharkiv. [in Ukrainian].

2. Bandurka, O. M. (2002) Operatyvno-rozshukova diialnist. Part. I. Kharkiv: Natsionalnyi universytet vnutrishnikh sprav. [in Ukrainian].

3. Voskresenskij, G. M. (1985) Teorija i praktika informacionnogo obespechenija upravlenija v organah vnutrennih del. Moskva: Akademija MVD SSSR. [in Russian].

4. Operatyvno-rozshukova diialnist orhaniv vnutrishnikh sprav. (1999) Zahalna chastyna. Vol. 1. E. O. Didorenko et. al. L. V. Borodycha (Ed.). Luhansk: Luhanskyi instytut vnutrishnikh sprav. [in Ukrainian].

5. Kozachenko, I. P., Rehulskyi, V. L. (1999) Pravovi, moralno-etychni ta orhanizatsiini osnovy operatyvno-rozshukovoi diialnosti. Lviv: Lvivskyi instytut vnutrishnikh sprav pry Natsionalnii akademii vnutrishnikh sprav Ukrainy. [in Ukrainian].

6. Protydiia oderzhanniu nepravomirnoi vyhody sluzhbovoiu osoboiu pidrozdilamy zakhystu ekonomiky natsionalnoi politsii Ukrainy. (2017) A. M. Lysenko et. al. Kharkiv: Vydavnytstvo «Fort». [ in Ukrainian]. 
7. Lysenko, A. M. (2008) Pravovi ta orhanizatsiino-taktychni osnovy rozkryttia zlochyniv u sferi vyhotovlennia ta zbutu alkoholnykh napoiv. Extended abstract of candidate's thesis. Kharkiv. [in Ukrainian].

8. Pro informatsiiu : Zakon Ukrainy vid 02 zhovt. 1992 r. № 2657-XII. URL: https://zakon.rada.gov.ua/laws/show/2657-12 [in Ukrainian].

9. Atmazhitov, V. M. (1984) Realizacija operativno-rozysknoj informacii. Moskva: Akademija MVD SSSR. [in Ukrainian].

10. Perepelytsia, M. M., Zhuravlov, V. Yu. (1999) Deiaki teoretychni aspekty informatsiinoho zabezpechennia operatyvno-rozshukovoi diialnosti orhaniv vnutrishnikh sprav. Visnyk Natsionalnoho universytetu vnutrishnikh sprav - Bulletin of the National University of the Interior, issue 1, 37-46. [in Ukrainian].

11. Dusheiko, H. O. (2001) Orhanizatsiino-taktychni osnovy realizatsii operatyvnorozshukovoi informatsii na stadii porushennia kryminalnoi spravyю Extended abstract of candidate's thesis. Kharkiv. [in Ukrainian].

12. Minka, P. Ya. (2003) Poperedzhennia operatyvno-rozshukovymy zakhodamy zlochynnykh posiahan na vantazhi. Extended abstract of candidate's thesis. Kharkiv. [in Ukrainian].

13. Osnovy operativno-rozysknoj dejatel'nosti. (2001) V. B. Rushajlo (Ed.). SanktPeterburg: Lan'. [ in Ukrainian].

14. Pro operatyvno-rozshukovu diialnist: Zakon Ukrainy vid 18 liut. 1992 r. № 2135XII. (1992) URL: https:/ / zakon.rada.gov.ua/laws/show/2135-12. [in Ukrainian].

Стаття надійшла до редколегї 02.09.2019

Лысенко А. H., кандидат юридических наук, доцент, доцент кафедры оперативно-розыскной деятельности Харьковского национального университета внутренних дел (г. Харьков, Украина)

Лысенко И. В.,

кандидат юридических наук, доцент, доцент кафедры права Национального технического университета «Харьковский политехнический институт»

(г. Харьков, Украина)

Перевалова Л. В., кандидат философских наук, доцент, заведующий кафедры права Национального технического университета «Харьковский политехнический институт (г. Харьков, Украина)

\section{ИНФОРМАЦИОННО-АНАЛИТИЧЕСКОЕ ОБЕСПЕЧЕНИЕ ОПЕРАТИВНО-РОЗЫСКНОЙ ДЕЯТЕЛЬНОСТИ ПО ПРОТИВОДЕЙСТВИЮ ТЕРРОРИЗМУ}

В данной научной статье рассматриваются содержание и сущность информационно-аналитического обеспечения оперативно-розыскной деятельности по противодействию терроризму с целью выявления 
существующих недостатков в этой сфере. Во время исследования были использованы результаты анализа большого количества специальной профессиональной литературы, законодательных актов, практического опыта противодействия преступлениям, связанным с террористической деятельностью, а также личного опыта работы в правоохранительных органах. Авторы внесли научно-обоснованные предложения по усовершенствованию информационноаналитического обеспечения данной деятельности.

Ключевые слова: информационно-аналитическое обеспечение, оперативнорозыскная информация, источники оперативно-розыскной информации, оперативно-розыскная деятельность, терроризм.

Lysenko A.,

Ph. D. in Law, Associate Professor, Associate Professor of the Department of operative-investigative activityand crime detection Kharkiv National University of Internal Affairs (Kharkiv, Ukraine) Lysenko I.,

Ph. D. in Law, Associate Professor, Associate Professor of the Department of Law National Technical University «Kharkiv Polytechnic Institute» (Kharkiv, Ukraine) Perevalova L.,

Ph. D. in Philosophical Sciences, Associate Professor, Head of the Department of Law National Technical University «Kharkiv Polytechnic Institute» (Kharkiv, Ukraine)

\section{INFORMATION AND ANALYTICAL SUPPORT OF OPERATIONAL-SEARCH ACTIVITY ON COUNTERACTION TO TERRORISM}

In the article, based on a comprehensive analysis of professional literature, practical experience of information and analytical support of operative and investigative activities in the field of counter-terrorism, the inherent disadvantages are highlighted and the ways of their solution are offered.

The effectiveness of countering terrorism depends on the level of awareness of the operational units' employees about the existing criminal proceedings. Without a sufficient amount of information, the counteraction to terrorism will be nonsystematic, accidental in nature. However, in practice there are significant shortcomings in the organization of information and analytical support for counter-terrorism, namely: the failure of individual operational workers to receive current operational information on the preparation of these crimes and those involved, to determine the sources of probable information, the inability to make the correct assessment get the information and use it in the most effective way.

The authors propose to solve these disadvantages by using administrative levers and taking measures for: 1) maintain the staff of the operational units, especially those with experience of practical activity for more than 5 years, and the creation of appropriate 
working conditions for this purpose, because the absence of experienced workers is negatively reflected in the training of new operational staff, which in the future leads to a decrease in the quality of information and analytical support their operational and investigative activities; 2 ) increase the level of initial professional training of operational units and the training of students in higher education institutions with specific learning conditions, by attracting experienced apprentices of operational units to work at applied departments, with the purpose of studying experience, mastering skills and skills of carrying out informational and analytical support operatively -development activities; 3 ) changes in the system of criteria for evaluating the operations of operational units by replacing the quantitative indicators of the revealed crimes on the assessment of the prevalence of crimes in the area of operational service, in order to reduce the burden on operational staff, which will enable them to focus on the quality of information and analytical support for their activities.

Key words: information and analytical support, operative-search information, sources of operative-search information, operative-search activity, terrorism.

DOI https://doi.org/10.33766/2524-0323.87.280-290

УДК 343.37:334.72

В. В. Лисенко,

доктор юридичних наук, професор, професор кафедри кримінального процесу та криміналістики Національного університету державної фіскальної служби України (м. Ірпінь, Україна) e-mail: charly_niron@i.ua iDhttps://orcid.org/0000-0003-1541-5105

\section{СИТУАЦІЇ, ЩО СКЛАДАЮТЬСЯ НА МОМЕНТ ВІДКРИТТЯ КРИМІНАЛЬНОГО ПРОВАДЖЕННЯ ЩОДО ЛЕГАЛІЗАЦІЇ ДОХОДІВ ЗЛОЧИННОГО ПОХОДЖЕННЯ}

На підставі аналізу діяльності правоохоронних та контролюючих органів, у статті проаналізовані особливості ситуаційного підходу до питання початкового етапу розслідування легалізації (відмивання) доходів злочинного походження (ст. 209 КК України). Розглянуто чотири ситуації надходження первинних матеріалів про факти легалізації доходів злочинного походження до слідчих підрозділів та прийняття процесуального рішення щодо відкриття кримінального провадження. Визначено особливості аналізу та оцінки первинних матеріалів.

Ключові слова: легалізація (відмивання) коштів злочинного походження; предикатні злочини; відкриття кримінального провадження; оперативнорозшукова діяльність; фінансовий моніторинг.

Постановка проблеми. Розслідування легалізації доходів злочинного походження (ст. 209, 209-1, ст. 306 КК України) є багатоаспектною проблемою, яка потребує комплексного використання сил та засобів різних правоохоронних і контролюючих органів. У цьому процесі важливе значення має відповідне накопичення та обмін різноманітною інформацією. Процес легалізації доходів () Лисенко В. В., 2019 